بررسى تأثير ويزگگىهاى خاك بر ميزان فرسايش در سطح زيررده خاك با استفاده از PCA (مطالعه موردى: دشت اردبيل)

شهلا احمدى قلى درق'، آيدا عباسى كلو "* و اباذر اسمعلىعورى

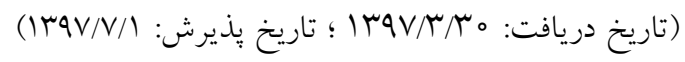

جكيده

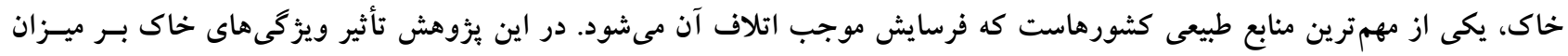

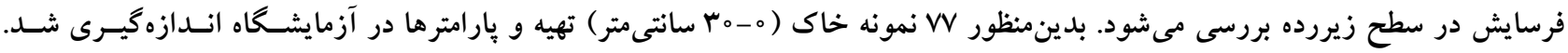

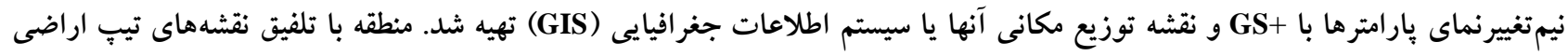

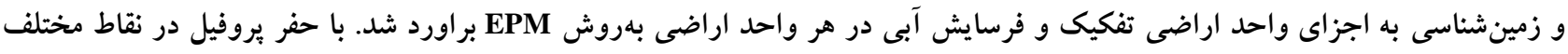

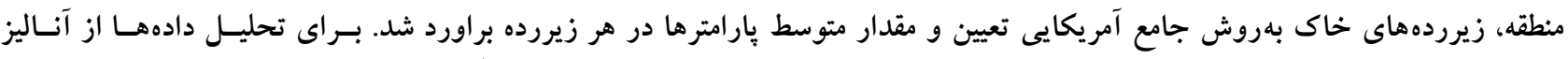

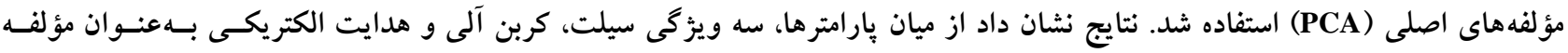

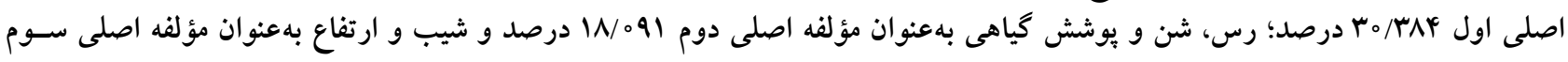

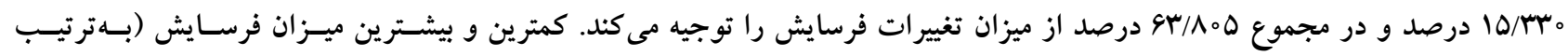

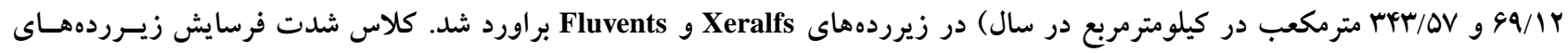
منطقه مطالعاتى، كم و متوسط تعيين شد.

وازههاى كليدى: آناليز مؤلفهاى اصلى، روش بتانسيل فرسايش، سيسم اطلاعات جغرافيايى، روش جامع آمريكايى

ا. كروه علوم و مهندسى خاك، دانشكده كشاورزى و منابع طبيعى دانشكاه محقق اردبيلى، اردبيل

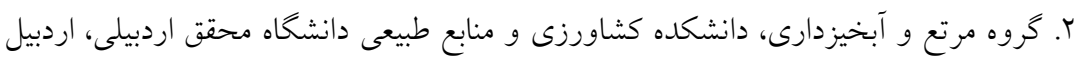

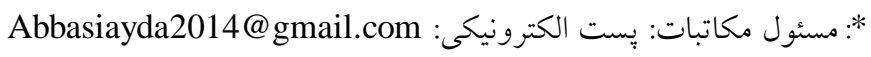


كَاهى در رخداد فرسايش خاك مؤثر هستند، اما زمان رخداد و

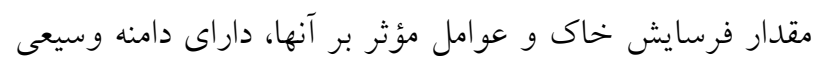

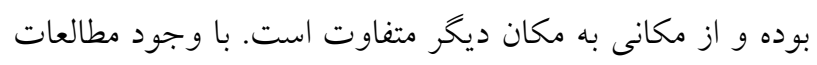

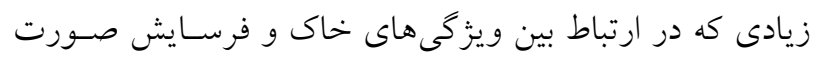

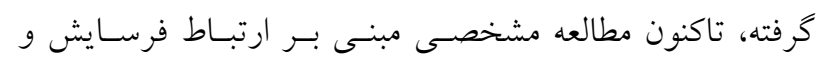

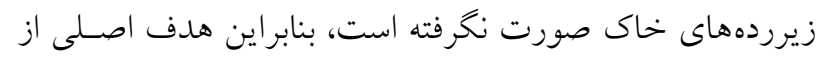

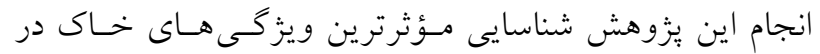

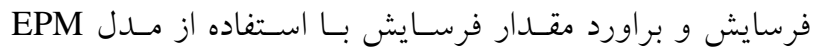

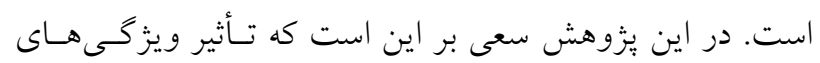

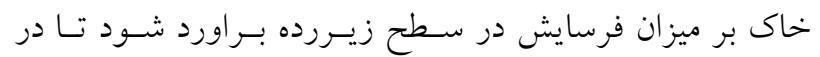

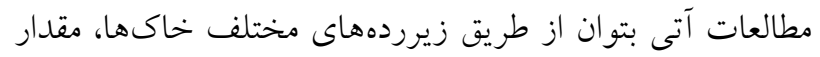
كلى فرسايش خاك را بيشبينى كرد.

\section{مواد و روشها}

مشخصات منطقه

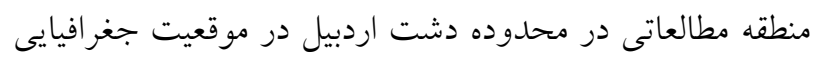

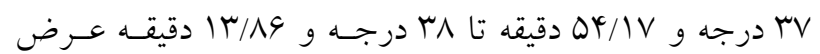

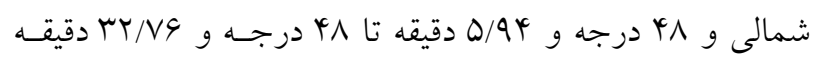

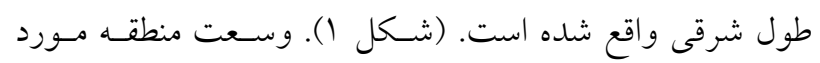

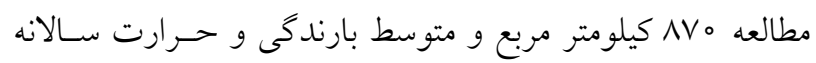

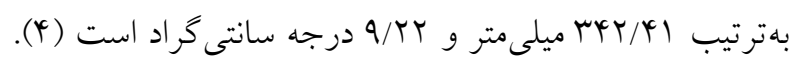

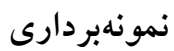
نقشههاى تويو گَرافى بهعنوان نقشه بِايه براى مطالعات انتخاب و و

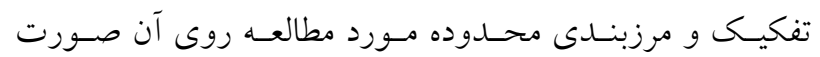
كرفت، منطقه نمونهبردارى در شيب صـفر تـا I ا درصـد قـرار داشت. نمونهبردارى به دو صورت سطحى و يروفيل انجام شد. نمونسهـــردارى سـطحى بــروش شـبكهبنــى مـنظم بـه ابعـاد

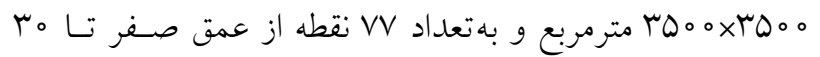
سانتى مترى خاك تهيه و براى اندازهگيرى ويزگى هاى فيزيكى و

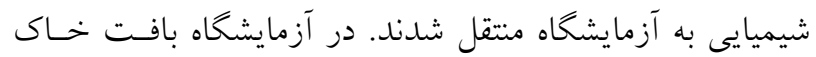
بهروش هيدرومترى (9)، هدايت الكتريكى در عصاره كل اشباع
خاك يكى از اصلى ترين منابع طبيعى است كه رشــ كَاهـان را

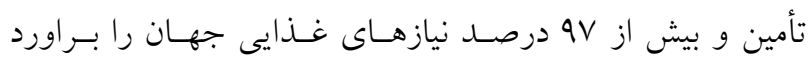

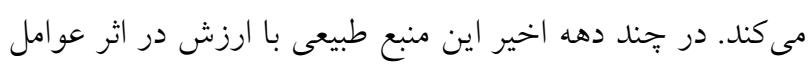

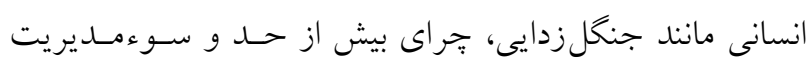

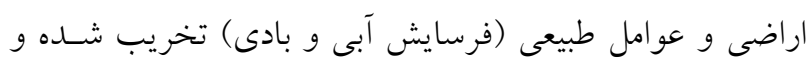

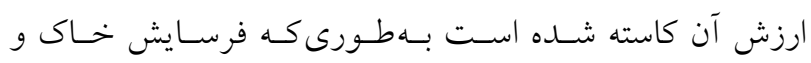

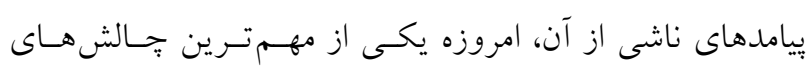
زيستمحيطى بهشمار مىرود (1) (1).

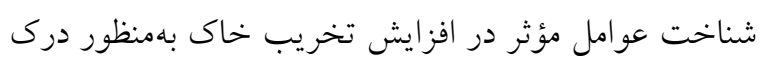

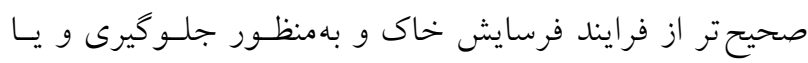
كاهش روند تخريب امرى ضرورى است (IV) و (II) (Y). محققان

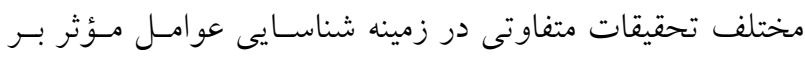

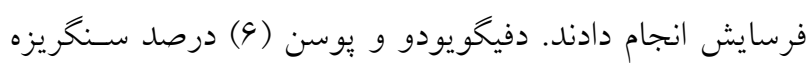

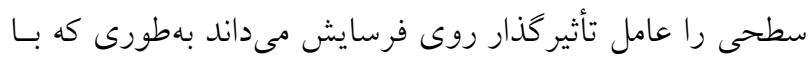

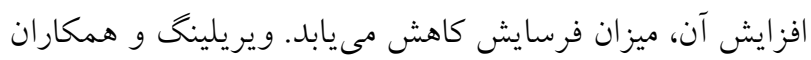

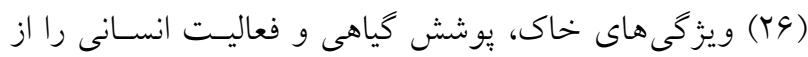

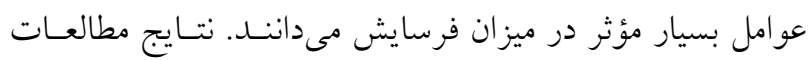

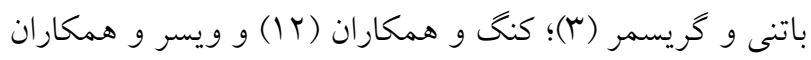

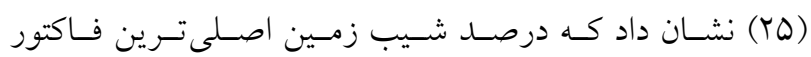

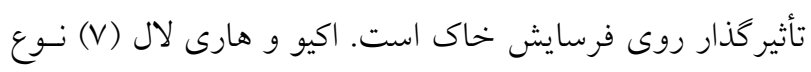

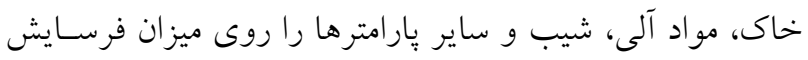

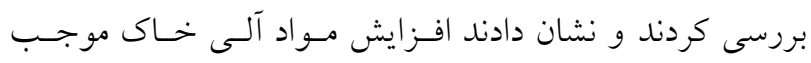

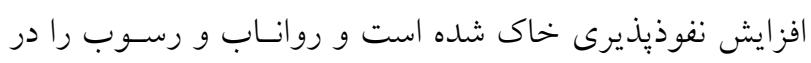
شيبهاى مختلف كاهش مىدهد. ميزان فرسايش در خاك شنى لومى نسبت به رسى لومى و رسى بيشتر بوده است.

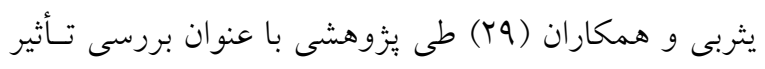

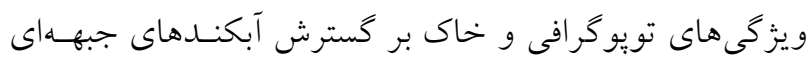

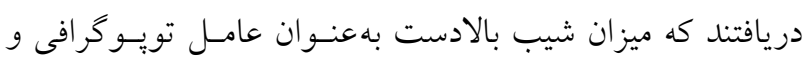

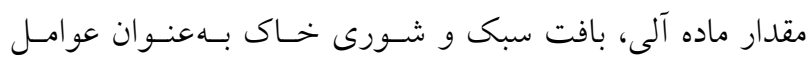
خاكى بيشترين تأثير را بر ميزان فرسايش و توليد رسوب دافي دارند.

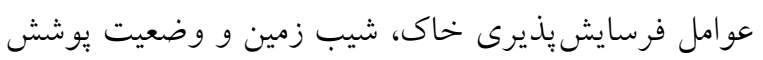




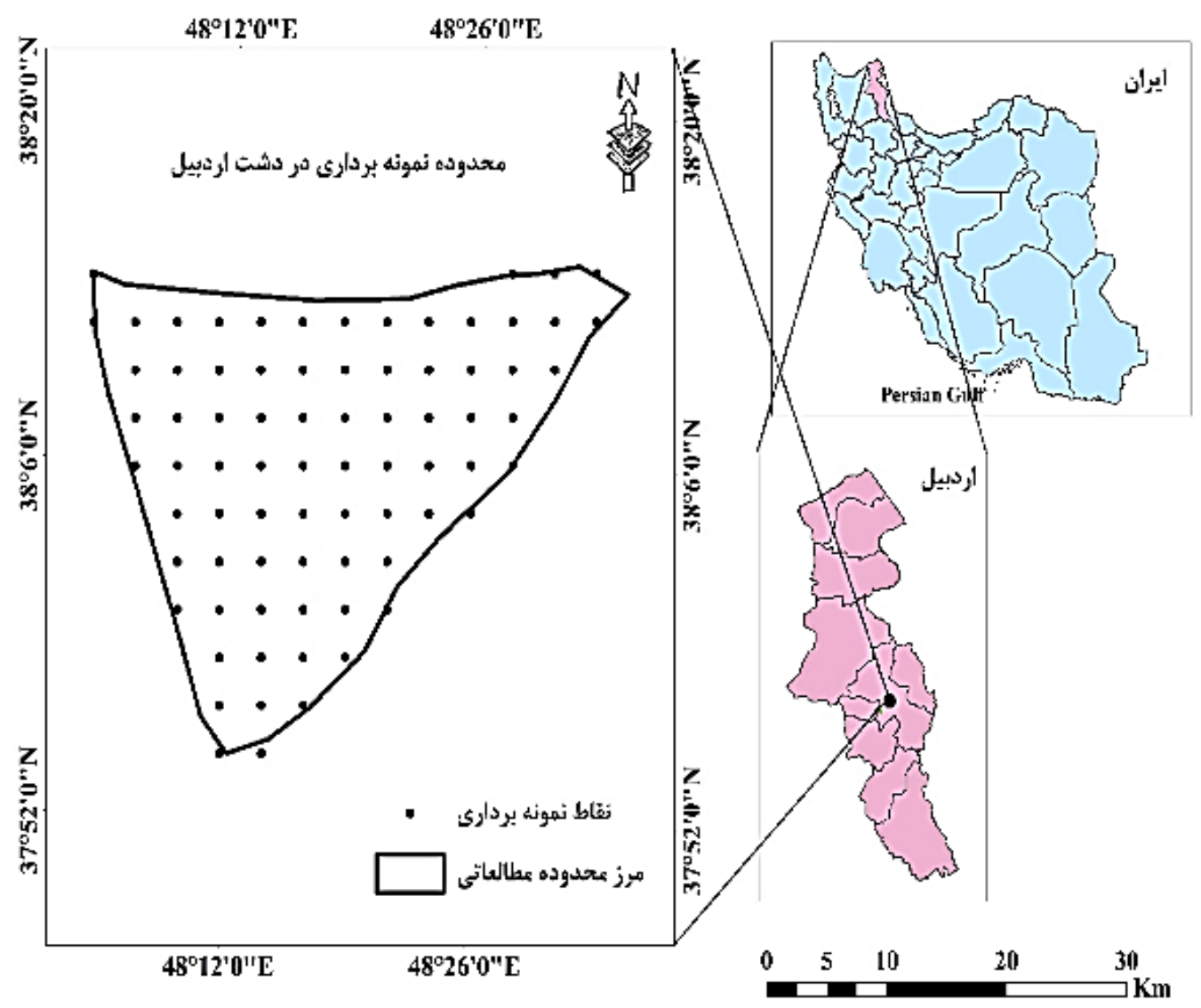

شكل ا. موقعيت منطقه مطالعاتى و نقاط نمونهبردارى

بهوسيله هدايتسـنج الكتريكى (م (1)، اسـيديته خــاك در خـل براورد فرسايش

ميزان فرسايش در هريك از اجزاى واحد اراضى بـا اسـتفاده از روش E.P.M (Erosion Potential Method) براورد شد. روش ي.ج روش كمّى است كه در آن شدت فرسايش توسـط جهار عامل ضريب استفاده از زمين، ضريب حساسيت سـنگ و خاى به فرسايش، وضسعيت فعلى فرسـايش و شـيب عرصـه

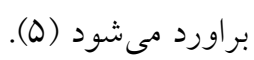

تجزيه آمارى و زمين آمارى

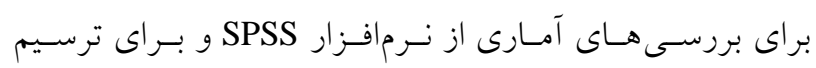
نيم تغييرنما، برازش مدل مناسب و ترسيم نقشه بر اكنش هركدام از پيارامترهاى مورد بررسى از نرمافزار GS و ArcMap استفاده

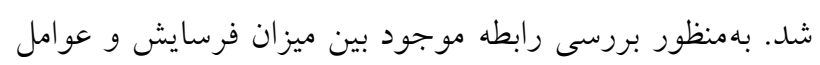
تعيين شده و نيز تعيـين مهـمتــرين عامـل يـا عو امـل مـؤثر در
اشباع با استفاده از متر (1)، كربن آلى بهروش و الكلىبلـى

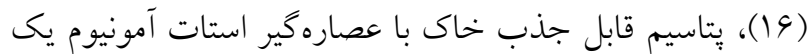
نرمال (سا) و نيتروزن كل خاك بـهروش كجلـدال (11) تعيسين شدند. به منظـور بررسـى درصـد يوشـش گيـاهى در صـحرا از

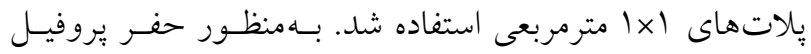
براى ردهبندى خاك، نقشههاى زمينشناسى، كـاربرى اراضسى و شيب در محيط ArcMap با هم تلفيق و نقشه واحد كارى تهيـه شد شكل (Y). سبّ در هر كدام از واحدهاى كارى تعداد يــنج يروفيل در كل منطقه تشريح شد. ويزگى هـاى لازم بـراى هـر يروفيل ثبت و نمونههاى افقهاى مشخصه براى انجام آناليزهاى

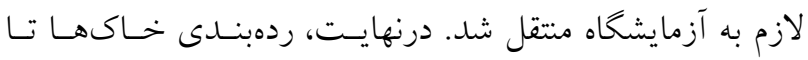

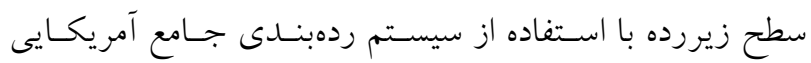
صورت كرفت. 


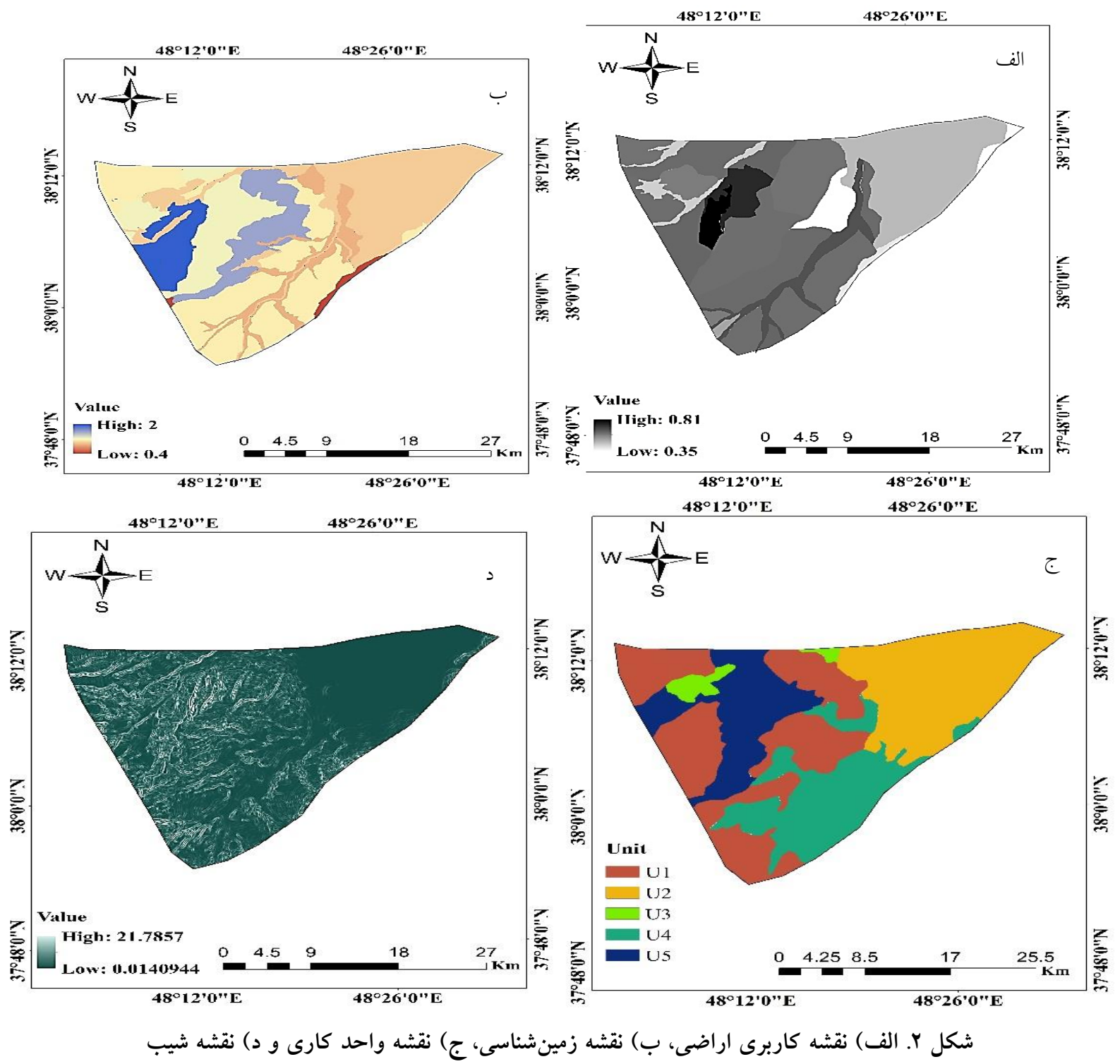

بيشترين مقدار حداكثر مربوط به بارامتر يتاسيم است.

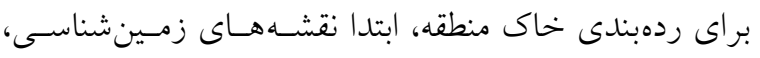

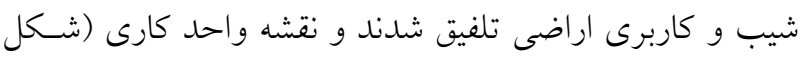

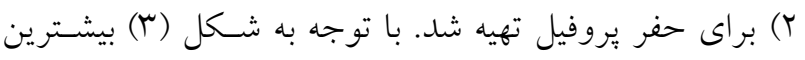

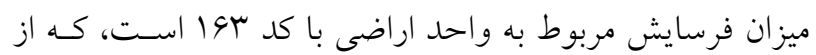

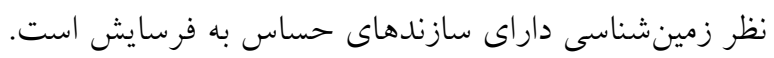
براساس ردهبندى جامع آمريكايى، خاكهاى مـورد مطالعهـ

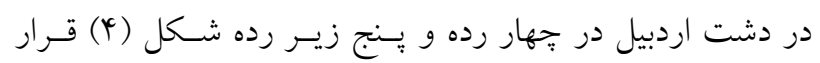

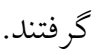
نتايج اجراى PCA روى لا فاكتور و در Vr واحسد اراضى
تغيــرات فرسـايش از روش آنـاليز مؤلفـهـــاى اصـلى (PCA)

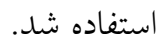
نتايج و بحث جدول (1) توصيف آمارى پارامترهاى مـورد بررسى را نشـان

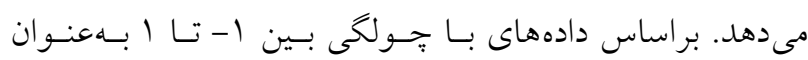

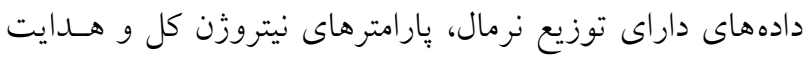

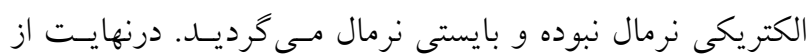

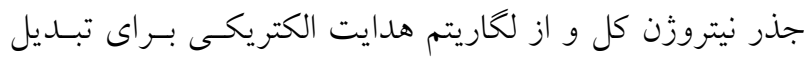

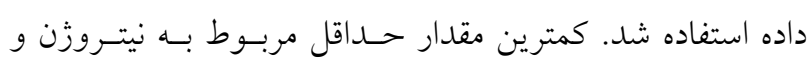


جدول ا. آمار توصيفى ويزَى هاى نمونهاى سطحى

\begin{tabular}{|c|c|c|c|c|c|c|}
\hline انحراف معيار & ميانخين & 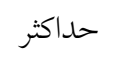 & 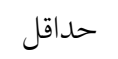 & كشيدگى & جولى & متغيرهاى خاى \\
\hline.$/ 099$ & $1 / 10 \wedge$ & T/YIT &.$\% 9 V$ & $1 / 94 V$ & o/var & كربن آلى (\%) \\
\hline Q/DG & 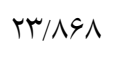 & YQ/IKT & $9 / V 11$ & $-0 / 4 \wedge 1$ & $0 / 9 \circ 0$ & رس (٪\%) \\
\hline $11 / 901$ & $K Y /|F|$ & $V \pi / \circ \Delta 1$ & $|9 / 0 T|$ &.$/ T V V$ & $0 / r 90$ & شن (\%) \\
\hline $9 / 199$ & $m / 9 \wedge 9$ & YN/GGT & IV/99T & $-0 / 09 V$ & $-0 / \pi V$ & سيلت (٪) \\
\hline$\circ / \Lambda M$ &.$/ 90 \mathrm{r}$ & $\Delta / V T_{0}$ & $\circ / T \Delta \Delta$ & $11 / 9 r \Lambda$ & $r / 1 \circ 4$ & هدايت الكتريكى (dS/m) \\
\hline$\circ / \circ \Delta \Delta$ &.$/ 111$ & $\circ / \pi \Delta \circ$ & . & $\Delta / 4 \circ r$ & $1 / A V r$ & نيتروزن كل (.) \\
\hline $14 / 990$ & $4 / 091$ & $Q T / Y \wedge 1$ & $T Y / 09 V$ & $0 / 9 V \pi$ & $0 / 991$ & يتاسيم (ppm) \\
\hline.$/ 100$ & V/GTK & V/ake & $V /(0)$ & $1 / 494$ & $-0 / 941$ & اسيديته \\
\hline $9 / 9 M K$ & $\pi r / 919$ & Kr/QRT & $|r / Q T|$ & $\circ / q^{*}$ & $\circ / V T V$ & رطوبت اشباع وزنى (٪) \\
\hline
\end{tabular}

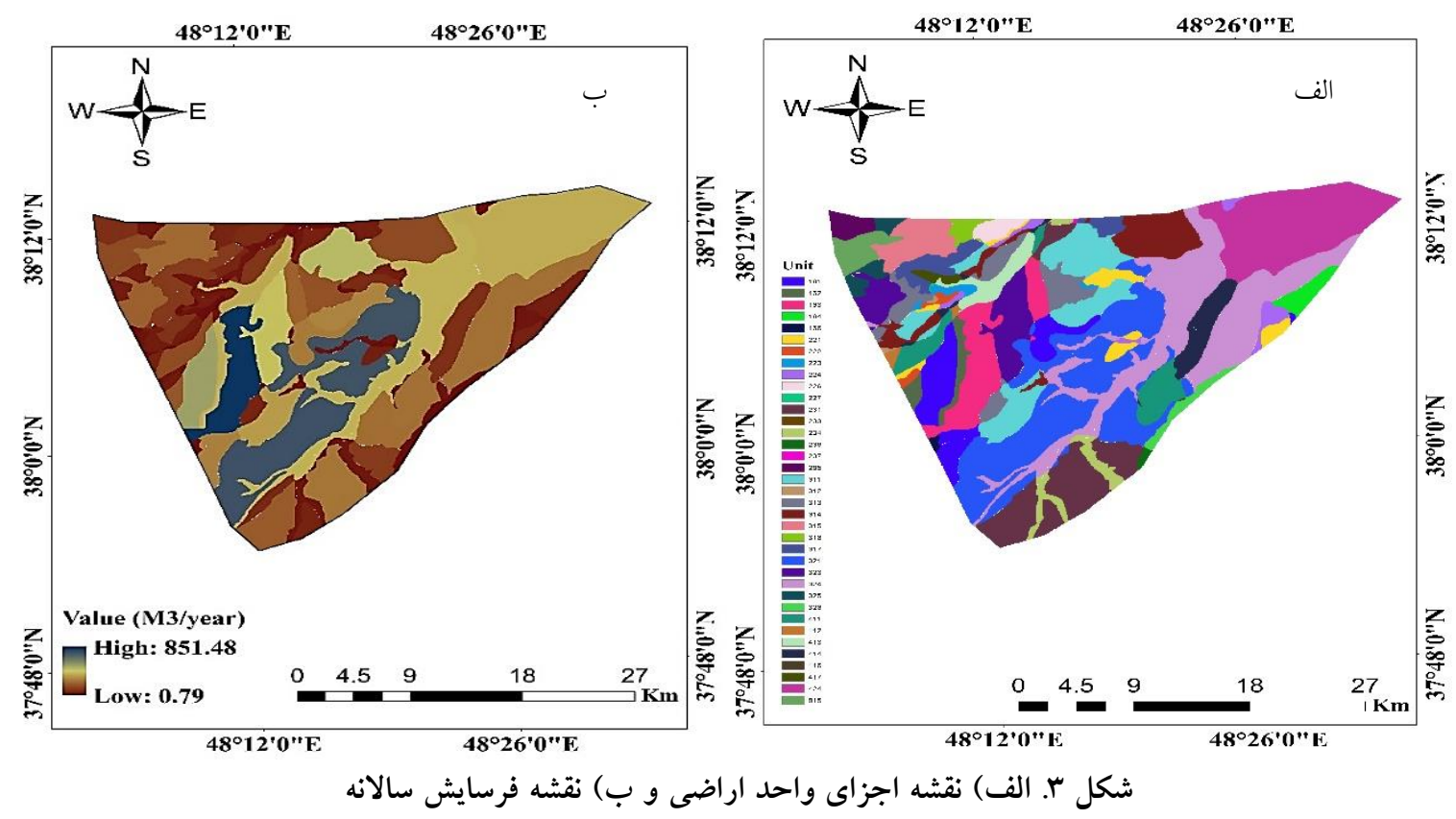

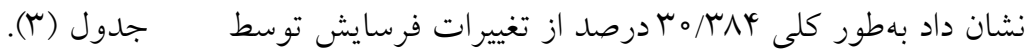
نمودار مؤلفههاى اصـلى اول و دوم در شـكل ه نشـان داده

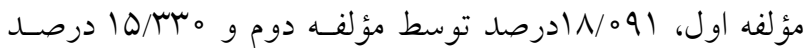

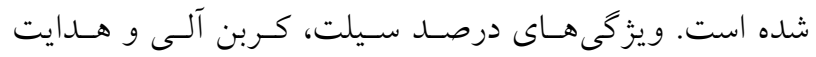

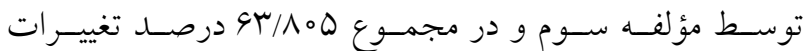
الكتريكى روى محور اول و ويزگكىهـاى درصــ رس، شـن و و فرسايش توسط سه مؤلفه اول قابل توجيه هسـتند جــدول (Y). يوشش گياهى روى محور دوم قرار مى گيرند.

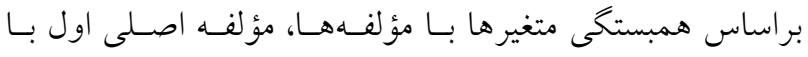

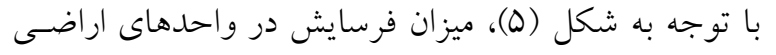
IU

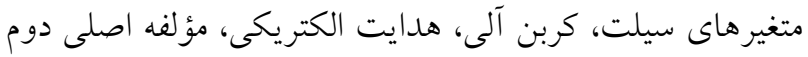

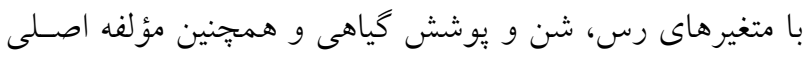
قوى با ويزگكىهـاى محسور اول (مستقيم بـا سـيلت و هــايت

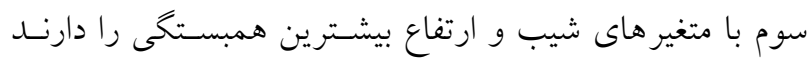




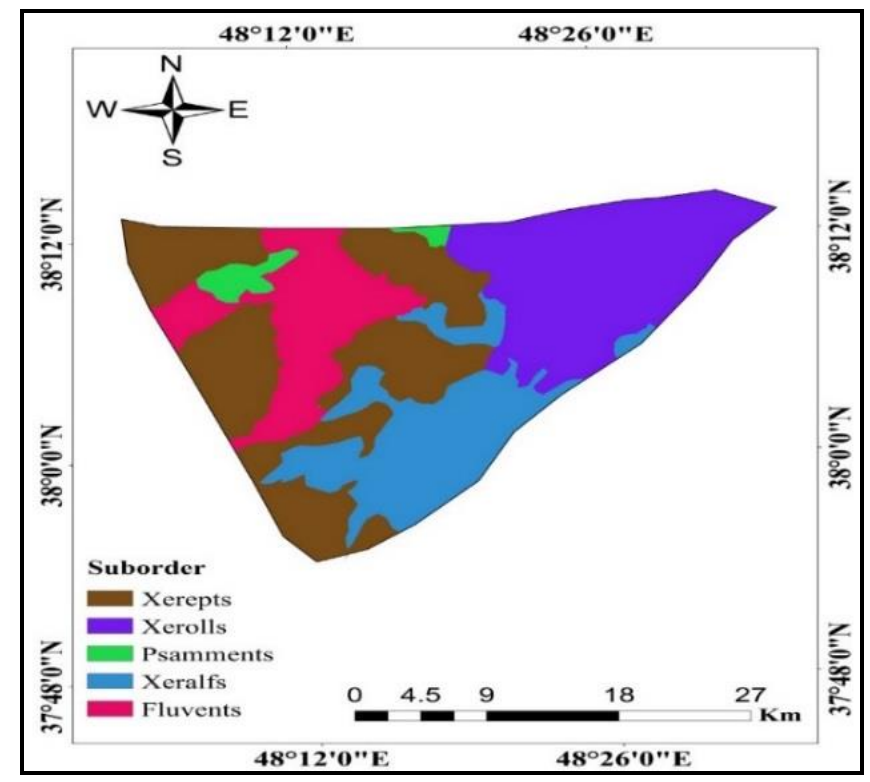

شكل f. نقشه زير ردههاى خاك منطقه مطالعاتى

\begin{tabular}{|c|c|c|c|}
\hline واريانس تجمعى توجيهشده (.) & واريانس توجيهشده (٪) & مقادير ويزه & مؤلفه \\
\hline$\mu \circ / \mu_{\Lambda} \boldsymbol{\varphi}$ & ro/rरr & $r / 90^{\circ}$ & 1 \\
\hline YNAKVG & $1 N / \circ 91$ & r/TUT & r \\
\hline$q \pi / \Lambda \circ \Delta$ & 10/\%。 & $1 / 994$ & r \\
\hline
\end{tabular}

ارتباط ضعيفى با ويزگىىهـاى محسور دوم (مستتيم بـا رس و بوشش گياهى و معكوس با شن) دارد. نمودار مؤلفههاى اصلى اول و سوم در شكل (9) نشان داده شده است. ويزز كىهـاى درصـد سـيلت، كـربن آلى و هــدايت الكتريكى روى محور اول و خصوصيات درصد شيب و ارتفـاع روى محسور دوم قـرار مسى گيرنـــ. طبـق شـكل (9) در بيشـتر

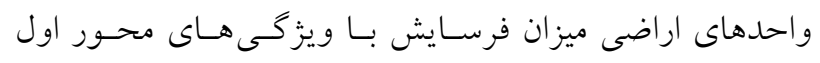
ارتباط قوى (مستقيم با سيلت و هدايت الكتريكى و معكوس با

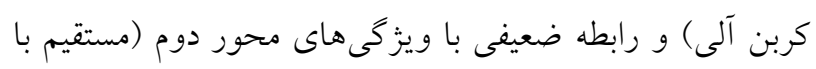
ارتفاع و شيب) دارد.

نتايج PCA نشان داد كه از 11 ويزگ

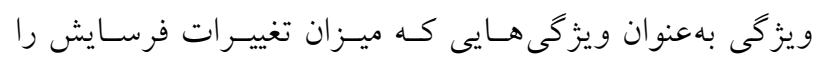

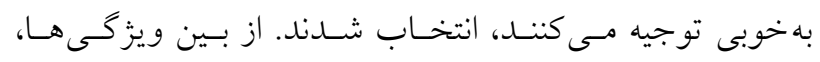

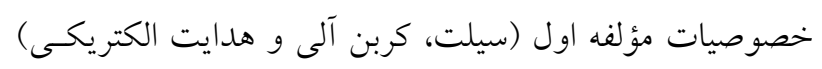

الكتريكـى و معكـوس بــا كـربن آلىى) و رابطـه ضـعيفى بــا ويزّكى هاى محور دوم (معكوس با رس، شن و بوشش گياهى) دارند. در واحد اراضى هال ميزان فرسايش داراى ارتباط تقريباً

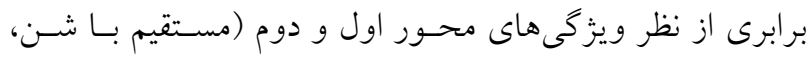
رس، كربن آلى و بوشش كياهى و معكوس با سيلت و هــايت

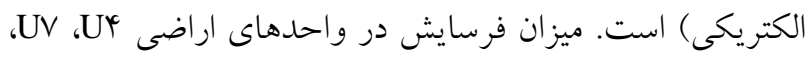
r رابطه بسيار قوى با ويزخى Uهـاى محسور اول (مسـتقيم بـا سيلت و هدايت الكتريكى و معكوس با كـربن آلى) و ارتبـاط ضعيف با ويزخى هــاى محسور دوم (معكسوس بـا رس، شـن و يوشش گياهى) دارد. در واحدهاى اراضى U9، UA، U1 •

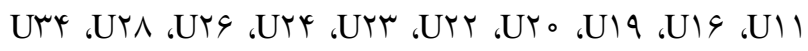
و هس Uيزان فرسايش با ويزّكىهاى محسور اول ارتبـاط قـوى (مستقيم با سيلت و هدايت الكتريكى و معكوس با كربن آلى) و 


\begin{tabular}{|c|c|c|c|}
\hline \multicolumn{4}{|c|}{ جدول r. عوامل اصلى مؤلفه هاى مؤثر در ميزان فرسايش خاك در واحدهاى اراضى } \\
\hline 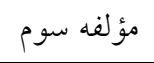 & 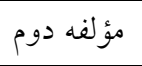 & مؤلفه اول & عامل \\
\hline$-\circ / \circ \Delta r$ & ०/A91 & $\circ / \Upsilon \wedge \Lambda$ & رس \\
\hline$\circ / \circ \Delta Y$ & $-\circ / V Q r$ & $-0 / 099$ & شن \\
\hline ०/०५० & 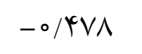 & $0 / 9 Y \wedge$ & سيلت \\
\hline$\circ / \mu_{\Lambda}$ & $0 / 4 \& \Lambda$ & $0 / 109$ & يتاسيم \\
\hline$-0 / M r$ & $\circ / Y 9 \Lambda$ & $-0 / 99 \mathrm{~V}$ & 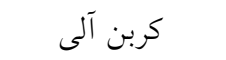 \\
\hline$-\circ / Y Q \circ$ & $0 / 191$ & $-0 / 490$ & 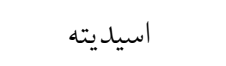 \\
\hline ./90r &.$/ 19 \wedge$ & $\circ / \mu \mathrm{V}$ & شيب \\
\hline o/ver & -o/TQR & $\circ / \mu \circ V$ & ارتفاع \\
\hline$-0 / Y V I$ & o/Q FV & $-0 / O Y \mid$ & يوشش كياهى \\
\hline$-0 / 1 r_{q}$ & $0 / Y 99$ & $\circ / 199$ & نيتروزن كل \\
\hline .011 & ०/O० & $\circ / \Delta V Y$ & هدايت الكتريكى \\
\hline
\end{tabular}

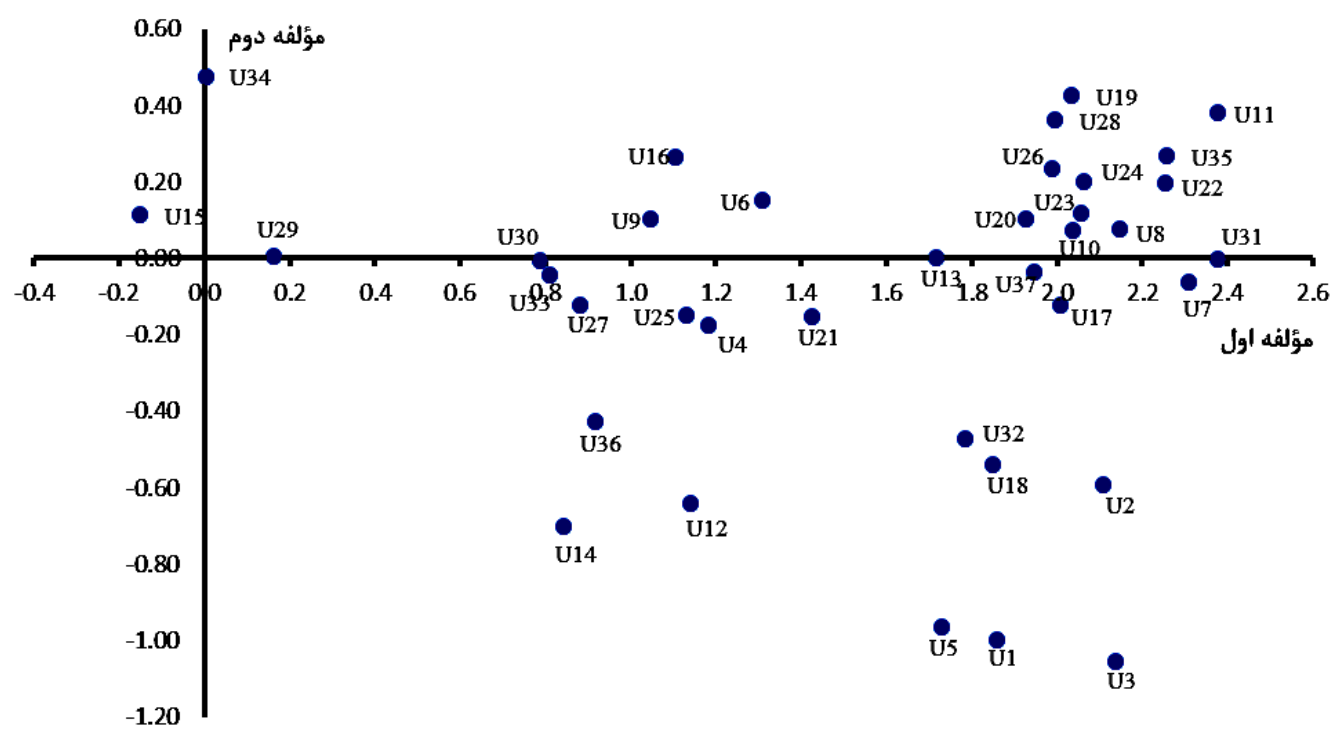

شكل ه. نمودار براكنش واحدهاى اراضى در ارتباط باعوامل مؤثر در منطقه مورد مطالعه با استفاده از آناليز مؤلفههاى اصلى

عقلانى از خاكها و بــهــارگيرى روشهــاى كارامــ حفاظـت

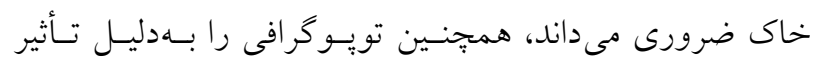

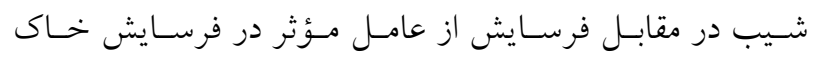

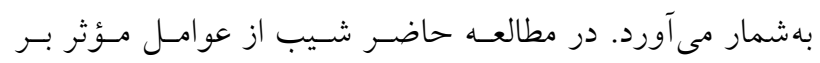

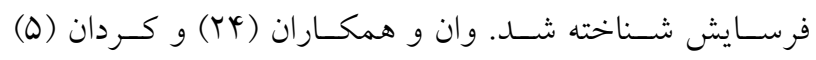

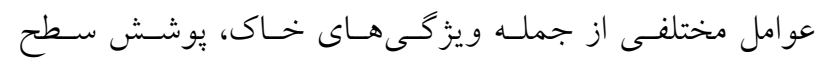

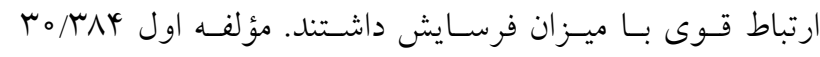

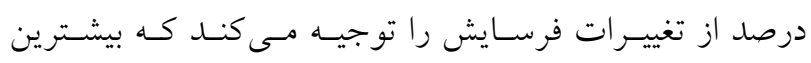

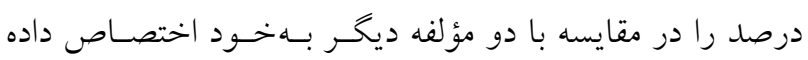

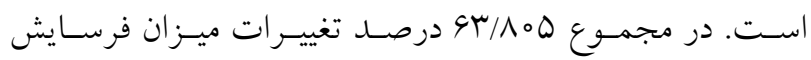

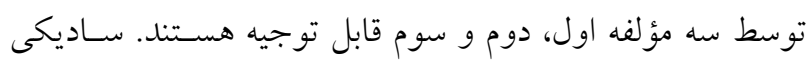

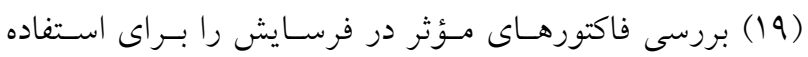




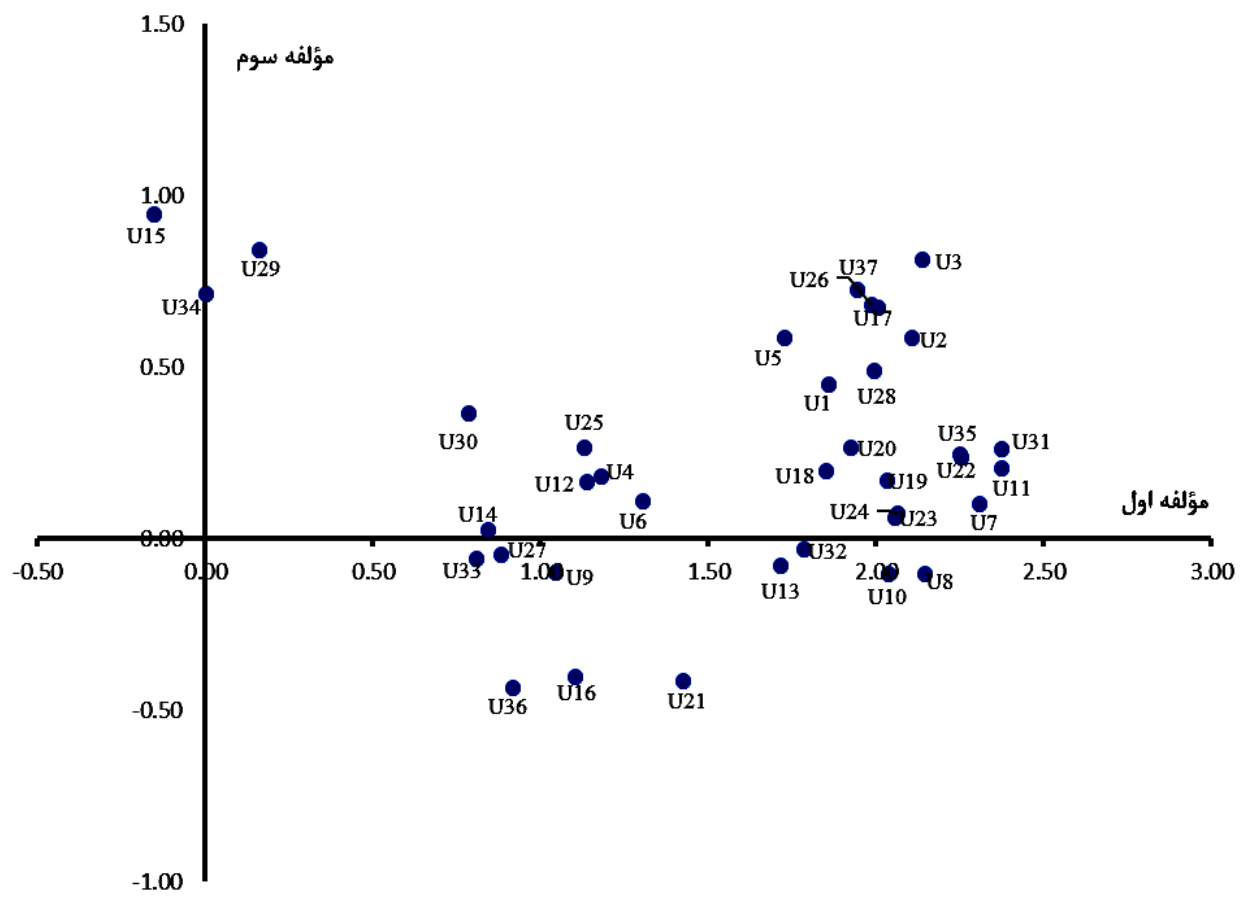

شكل 9. نمودار براكنش واحدهاى اراضى در ارتباط با عوامل مؤثر در منطقه مورد مطالعه با استفاده از آناليز مؤلفه هاى اصلى

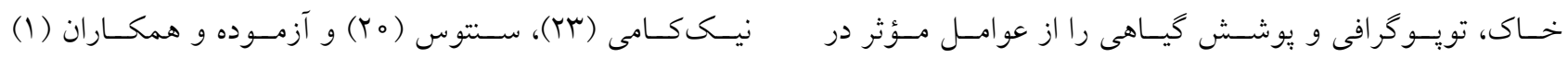

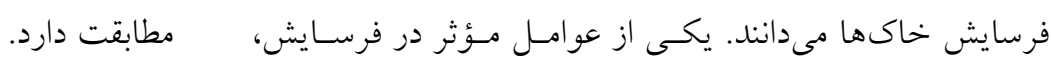

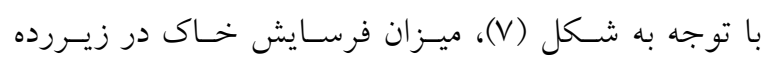

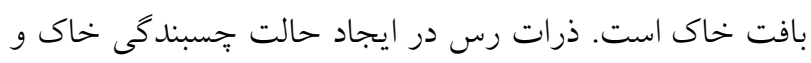

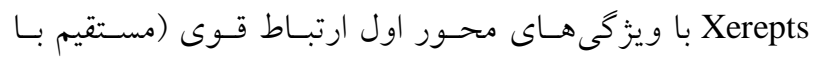

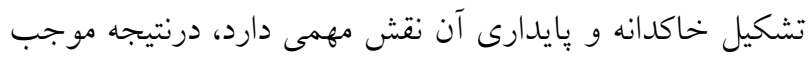

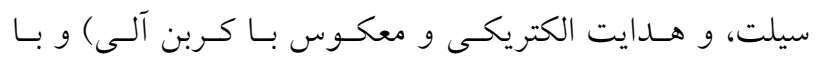
كاهش فرسايش مى شوند (YV). بنابه نتايج اين يـرَوهش ميـزان

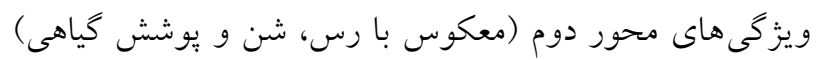

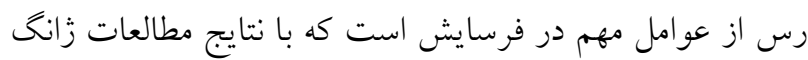
ارتباط ضعيفى دارد. ميـزان فرسـايش در ايسن زيـررده 19r/9V و همكاران (ץ) مطابقت دارد. بهدليـل ارتبـاط نزديـك مقـدار مترمكعب بر كيلومترمربع در سال است. شدت فرسايش در اين سيلت با فرسايش يذيرى، ميزان فرسايش خاك افزايش مى يابد،

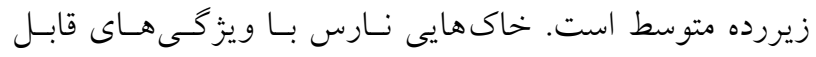

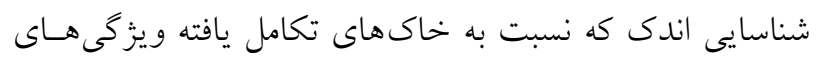

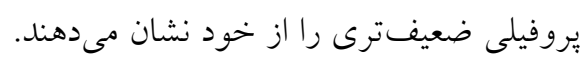

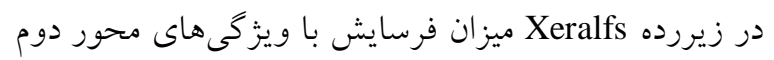

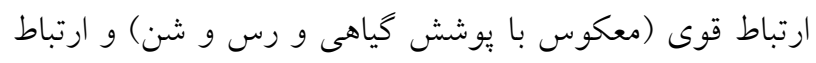

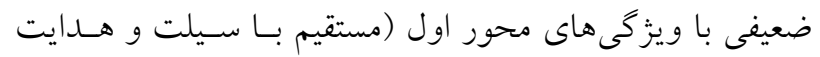

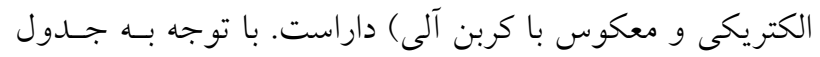

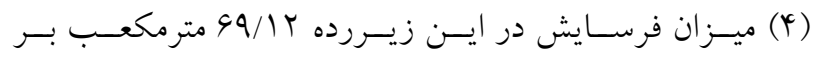

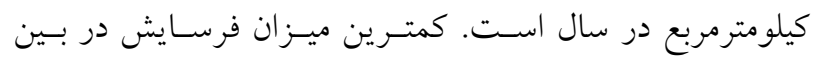

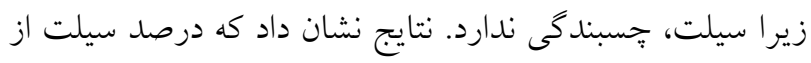
عوامل تأثير گذار در ميزان فرسايش در منطقه مورد مطالعه است

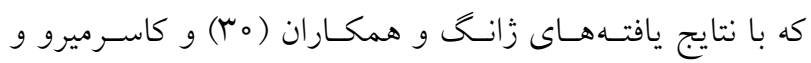

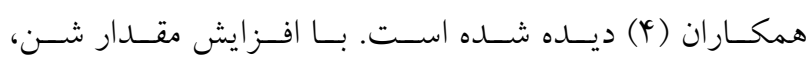

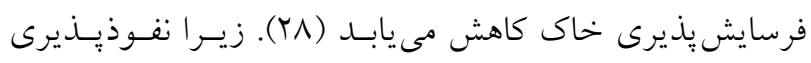

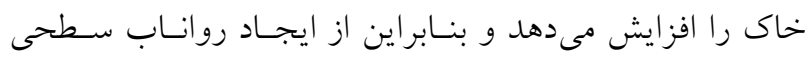
جلو گيرى مى كند و باعث كاهش فرسايش خاك مى شود (1). در مطالعه حاضر درصد شن از عوامل مؤثر در ميـزان فرسـايش

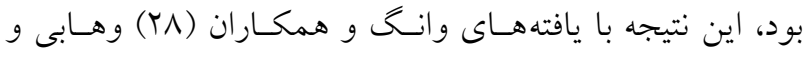




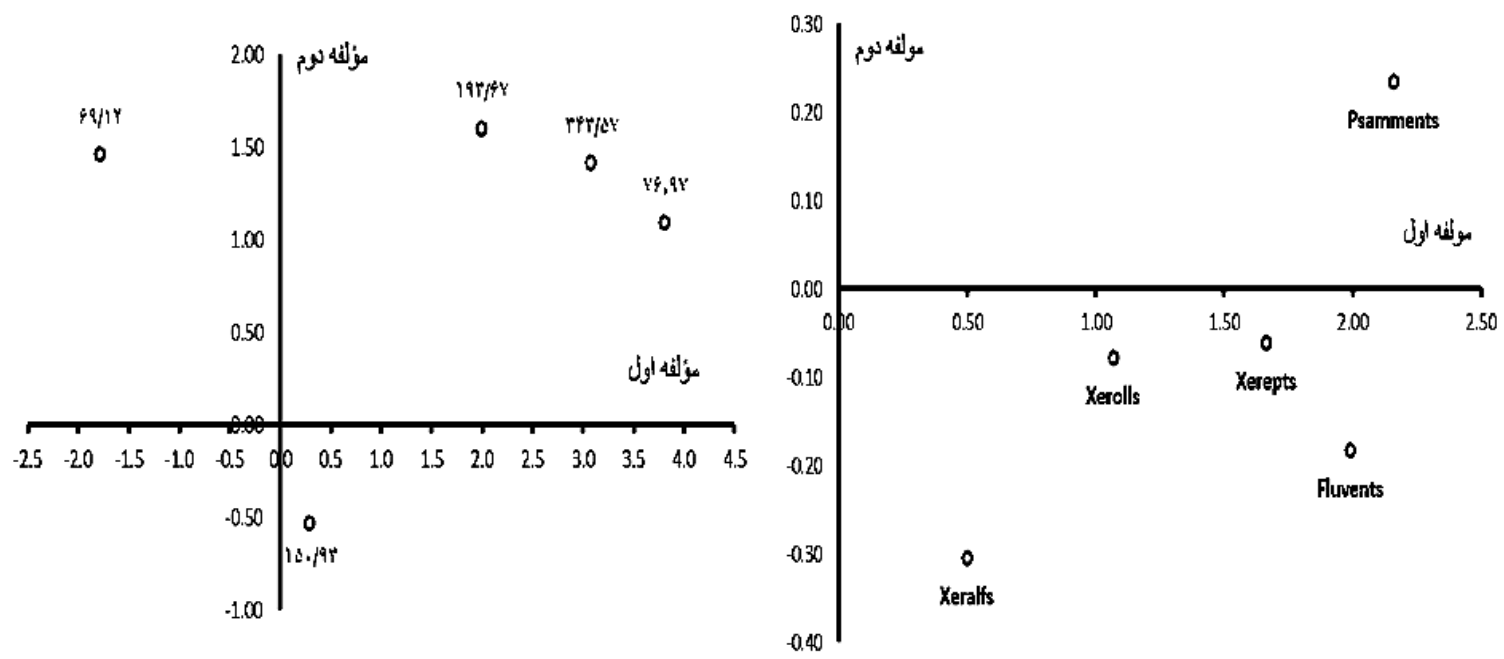

شكل V. نمودار بر اكنش زيرردهها در ارتباط با عوامل مؤثر در منطقه مورد مطالعه با استفاده از آناليز مؤلفههاى اصلى (راست) و نمودار

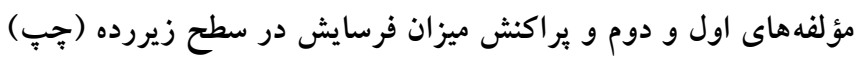

جدول Y. نتايج PCA عوامل مؤثر در ميزان فرسايش خاك در سطح زيررده

\begin{tabular}{|c|c|c|c|c|}
\hline شدت فرسايش & $\begin{array}{c}\text { ميزان فرسايش } \\
\left(\mathrm{m}^{r} / \mathrm{km}^{r} / \text { year}\right)\end{array}$ & مؤلفه دوم & مؤلفه اول & زيررده \\
\hline متوسط & $19 \pi / 9 \mathrm{~V}$ & $1 / 90$ & $1 / 99$ & Xerepts \\
\hline متوسط & $100 / 9 \pi$ & $-\circ / \Delta \mu$ & $0 / \pi q$ & Xerolls \\
\hline كم & $99 / 1 r$ & $1 / 49$ & $-1 / 29$ & Xerallfs \\
\hline متوسط & TKM/OV & $1 / K T$ & $r / \circ \Lambda$ & Fluvents \\
\hline كم & $V 9 / 9 V$ & $1 / 09$ & $r / \Lambda 。$ & Psamments \\
\hline
\end{tabular}

خاكدانهازى، بايدارى خاكدانهها و افزايش نفوذيـذيرى شـده، درنتيجه باعث كاهش هلررفت خـاك مسىشـوند كـه بـا نتـايج مطالعات زانخ و همكاران ( آץ) مطابقت دارد. ميـزان فرسـايش در زيــررده Fluvents ارتبــاط قـوى بــا ويزگگى هاى محور اول (مستقيم با سيلت، هــايت الكتريكىى و معكوس با كربن آلى) و رابطه ضعيفى با ويز گیىهاى محور دوم

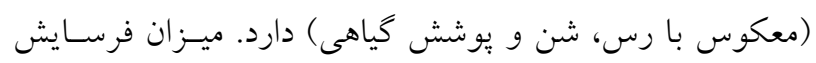
در اين زيررده از خاكها سال اسـت. شـدت فرسـايش در ايسن زيسررده متوسط اسـت بيشترين ميزان فرسايش در اين زيررده از خاى روى داده است. درصد سيلت در اين زيررده نسبت بـه سـاير زيـرردههـا بيشـتر
تمامى زيرردهها به اين زيررده تعلق دارد. ايسن زيــررده از نظـر شدت فرسايش در كلاس كم قرار دارد. در ايسن زيــررده خـاك

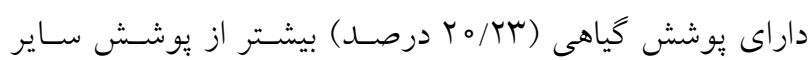
زيرردههاست كه اين بيوشش گيـاهى از طريـق حفاظـت سـطح خاك از برخورد مستقيم قطرات بـاران بـا ذرات خــاك و جــدا شدن آنها، سبب كاهش تخريب فيزيكى، كاهش سرعت جريان سطحى، كاهش تشكيل سله و افزايش نفوذ آب به خاك مىشود درنتيجه ميزان فرسايش خاك كاهش مى يابد. همجنـين در ايسن زيررده مقدار رس \|/ه درصد و مقدا كربن آلى T/V درصـد است، اين دو ويزگى از خـاك سـاير خصوصسيات فيزيكى و شـيميايى آن را تحــت شـعاع قـرار داده باعـث بهــود شـرايط 
كم، بهدليل افزايش نفوذيذيرى خاك كاهش مى يابد.

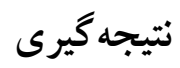

عوامل مختلفى در بديده فرسايش در طبيعت دخيل هستـند كـه

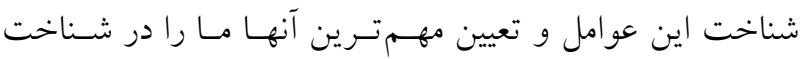

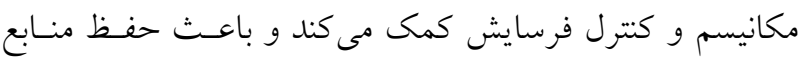

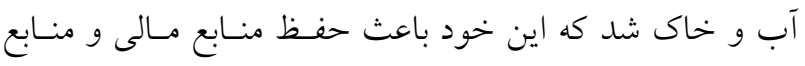
طبيعى شده و حركت در جهت توسعه بِايدار را ميسر مسى كنـد.

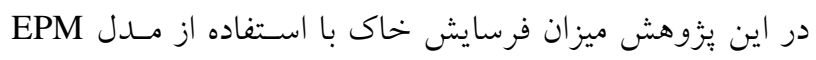

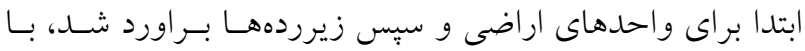

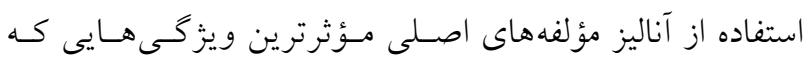

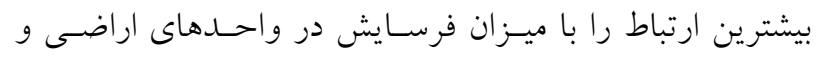

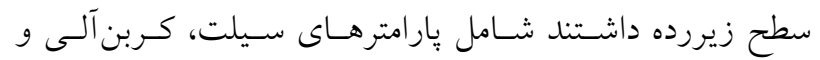

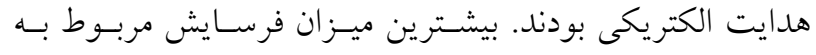

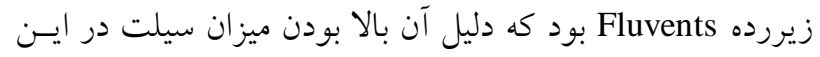
زيررده اسـت و كمتـرين ميـزان فرسـايش مربـوط بـهـ زيـررده Xeralfs است كه بهدليل رس بالاو كربن آلى بالا در اين كـروه

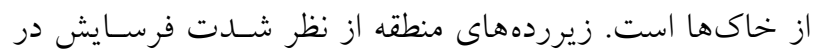

$$
\text { كلاس متوسط و كم قرار دارند. }
$$

است كه مى تواند دليل بالا بودن فرسايش در اين زيررده نسـبت

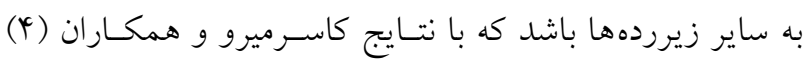

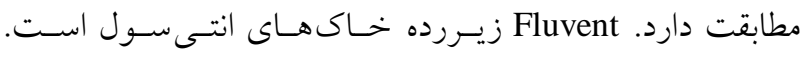
انتى سولها خاكهايى با تكامل ضعيف بـوده و بنـابراين ميـزان

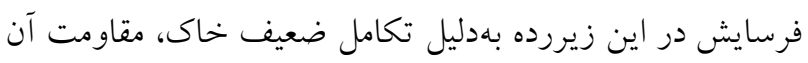
در برابر فرسايش كم بوده و هدررفت خاك بيشتر است. در زيررده Xerolls ميزان فرسـايش رابطـهـ بسـيار قـوى بـا سـا

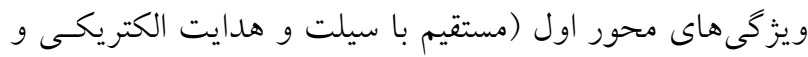

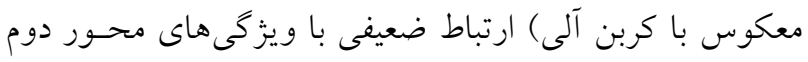

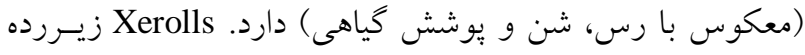

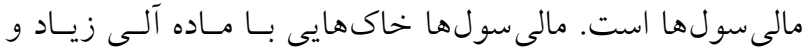
تكامل خوب هستند. خاكهاى اين زيررده داراى كلاس بافـت ستس لومى با كربن آلى ب r/ درصد باعث بهبـود شـرايط سـاختمان

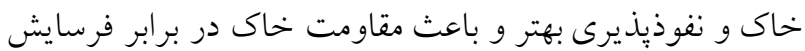
مىشود كه با نتايج واعظى و همكاران (YT) مطابقت دارد.

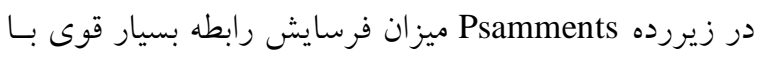

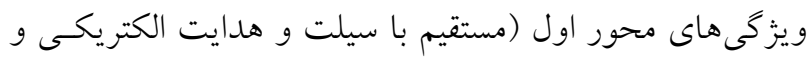

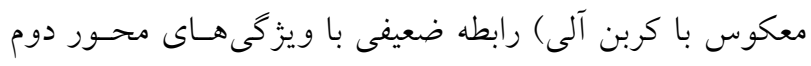

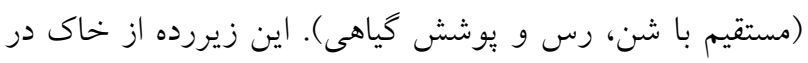

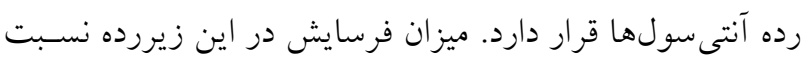

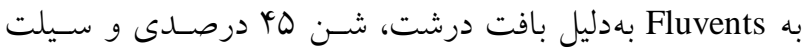

\section{منابع مورد استفاده}

1. Azmoodeh, A., A. Kavian, K. Soleimani, G. H. Vahabzadeh. 2010. Comparing runoff and soil erosion in forest, dry farming and garden land uses soils using rainfall simulator. Journal of Water and Soil 24(3): 490-500. (In Farsi).

2. Banaei, H. M. 1998. Soil Moisture and Temperature Regimes Map of Iran (1:2500000). Soil and Water Research Institute, Iran. (In Farsi).

3. Battany M. C. and M. E. Grismer, 2000. Rainfall Runoff and Erosion in Napa Velley vineyards: effects of slope, cover and surface roughness. Hydrological Processes 14: 1289-1304.

4. Casermeiro, M. A., J. A. Molina, M. T. Dela Cruz Caravaca, J. Hernando Costa, M. I. Hernando Massanet and P. S. Moreno. 2004. Influence of scrubs on runoff and sediment loss in soils of Mediterranean climate. Catena 59: 91107.

5. Cerdan, O. 2003. Long-term Soil Erosion Plot Data to evaluate the PESERA (Pan-European Soil Erosion Risk Assessment) Approach. European Geophysical Society, Geophysical Research Abstracts 1: 439.

6. De Figueiredo, T. and J. Poesen. 1998. Effects of surface rock fragment characteristics on interrill runoff and erosion of a silty loam soil. Soil \& Tillage Research 46: 81-95.

7. Ekwue, E. I. and A. Harrilal. 2010. Effect of soil type, peat and farmyard manure addition, slope and their interactions on wash erosion by overland flow of some Trinidadian soils. Biosystems Engineering 102: 236-243.

8. Ekwue, E. I. and A. Harrilal. 2010. Effect of soil type, peat, slope, compaction effort and their interactions on 
infiltration, runoff and raindrop erosion of some Trinidadian soils. Biosystems Engineering 105: 112-118.

9. Gee, G. W. and J. W Bauder. 1980. Particle-size analysis. In: Klutem, A. (Ed.), Methods of Soil Analysis, Part 1, Physical and Mineralogical Methods, Second edition, Agronomy, Soil Scienety of America, Madison, Wisconisin, USA.

10. Gupta, P. L. 2004. Soil, Plant, Water and Fertilizer Analysis. Agrobios Publications, India.

11. Jones, J. B. 2001. Laboratory Guide for Conducting Soil Tests and Plant Analysis. CRC Press LLC, USA.

12. Kang, S., L. Zhang, X. Song, S. Zhang, X. Liu, Y. Liang and S. Zheng. 2001. Runoff and Sediment Loss responses to rainfall and land use in two agricultural catchments on the Loss Plateau of China. Hydrological Processes 15: 977-988.

13. Knudsen, D., G. A. Peterson and P. F. Pratt. 1982. Lithium, sodium, potassium. Methods of Soil Analysis, Part 2 , Madison, Wisc: ASA-SSSA.

14. Li, X. Y. 2003. Gravel-sand mulchfor soil and water conservationin the semiarid loess region of northwest China. Catena 52: 105-127.

15. Maquaire, O., J. P. Malet, A. Remaitre, J. Locat, S. Klotz and J. Guillon. 2003. Instability condition of Marly hillslopes: towards landsliding or gullying? The case of the Barcelonnette Basin, South East France. Engineering Geology 70: 109-130.

16. Nelson, D. G. and L. E. Sommers. 1996. Total carbon, organic carbon and organic matter. Pp: 961-1010. In: D. L. Sparks (Ed.). In Methods of soil analysis; Part 3, Chemical Methods.

17. Okin, G. S., A. J. Parsons, J. Wainwright, J. E. Herrick, B. T. Bestelmeyer, D. C. Peters and E. L. Fredrickson. 2009. Do changes in connectivity explain desertification? Bioscience 59: 237-244.

18. Qiang Deng, Z., L. M. P. De Lima Joao and H. Shin Jung. 2008. Sediment transport rate-based model for rainfallinduced soil erosion. Catena 76: 54-62.

19. Sadiki, A. H. and A. Faleh. 2007. Assessing soil erosion and control factors by the radiometric technique in the Boussouad catchment, Eastern Rif, Morocco. Catena 71: 13-20.

20. Santos, F. L., J. L. Reis, O. C. Martins, N. L. Castanheria and R. P. Serralherio. 2003. Comparative assessment of infiltration, runoff and erosion of sprinkler irrigation soils. Biosystems Engineering 86: 355-364.

21. Turnbull, L., J. Wainwright and R. E. Brazier. 2008. A conceptual framework for understanding semi-arid land degradation : ecohydrological interactions across multiple-space and time scales. Ecohydrology 1: 23-34.

22. Vaezi, A. R., H. Bahrami, S. H. Sadeghi and M. H. Mahdian. 2008. The effect of physical and chemical properties on erodibility in calcareous soils. Journal of Soil and Water Sciences 22(1): 59-68. (In Farsi).

23. Vahabi J. and D. Nikkami 2008. Assessing dominant factors affecting soil erosion using a portable rainfall simulator. International Journal of Sediment Research 23: 375-385.

24. Van Rompaey, A. J. J., V. Vieillefont, R. J. A. Jones, L. Montanarella, G. Verstraeten and P. Bazzoffi. 2003. Validation of soil erosion estimates at European scale. EUR 20827 EN, 26pp. Office for Official Publications of the European Communities, Luxembourg.

25. Visser, S. M., G. Sterk and O, Ribolzi. 2004. Techniques for simultaneous quantification of wind and water erosion in semi-arid regions. Journal of Arid Environments 59: 699-717.

26. Vrieling, A., M. Steven de Jong, G. Sterk and S. C. Rodrigues. 2008. Timing of erosion and satellite data: A multiresolution approach to soil erosion risk mapping. International Journal of Applied Earth Observation and Geoinformation 10: 267-281.

27. Wakindiki, I. I. C. and M. Ben-hur. 2002. Soil Mineralogy and texture effects on crust micromorphology, infiltration and erosion. Soil Science Society of America 66: 597-605.

28. Wang, Y. Q., X. C. Zhang, J. L. Zhang and J. Shun. 2012. Spatialvariability of soil organic carbon in watershed on the loess plateau. Pedosphere 19: 486-495.

29. Yasrebi, B., M. Soufi, S. Mirnia and J. Mohamadi. 2013. Assessment the impact of topographic and soil characteristics on bank gullies dvancement in croplands, case study: Ilam province. Journal of Watershed Engineering and Management 5(1): 31-40. (In Farsi).

30. Zhang, K., S. Li, W. Peng and B. Yu. 2004. Erodibility of agricultural soils and loess plateau of China. Soil and Tillage Research 76: 157-165. 


\title{
Investigating the Effect of Soil Properties on Soil Erosion at Suborder Level Using PCA (A Case Study: Ardabil Plain)
}

\author{
SH. Ahmadi-Qolidaraq ${ }^{1}$, A. Abbasi-Kalo ${ }^{\star}{ }^{\star}$ and A. Esmali-Ouri ${ }^{2}$
}

(Received: June 20-2018; Accepted: September 23-2018)

\begin{abstract}
Soil is one of the most important natural resources of countries in which erosion occurs. In this research, the effect of soil characteristics on the amount of erosion at the suborder level was studied. For this purpose, 77 soil samples (0-30 $\mathrm{cm}$ ) were prepared and the parameters were determined in the laboratory. The semi-variograms of soil parameters and their spatial distribution maps were prepared with $\mathrm{GS}^{+}$and GIS, respectively. The study area was divided into work units by combining land use and geology maps and water erosion was estimated at each unit by the EPM method. By drilling profiles in different parts of study area, soil suborders were determined by Soil Taxonomy and the average values of parameters in each suborder was estimated. The principle components analysis (PCA) was then used for data analysis. The results showed that three parameters of silt, organic carbon and electrical conductivity could account for $30.384 \%$ as the first main component; clay, sand and vegetation could explain $11.189 \%$ as the second main component; and slope and height covered $15.330 \%$ as the third main component; in total, $63.805 \%$ percent of erosion variation could be justified by three main components. The lowest and highest amounts of erosion $\left(69.12\right.$ and $343.57 \mathrm{~m}^{3} / \mathrm{km}^{2}$, respectively) were estimated in Xeralfs and Fluvents suborders. The erosion class of suborders at the study area was determined to be "few" and "medium".
\end{abstract}

Keywords: Principal Components Analysis, Erosion Potential Method, Geographic Information system, Soil Taxonomy

1. Department of Soil Sciences and Engineering, Faculty of Agriculture and Natural Resources, University of Mohaghegh Ardabili, Ardabil, Iran.

2. Department of Range and Watershed Management, Faculty of Agriculture and Natural Resources, University of Mohaghegh Ardabili, Ardabil, Iran.

*: Corresponding Author, Email: Abbasiayda2014@gmail.com 